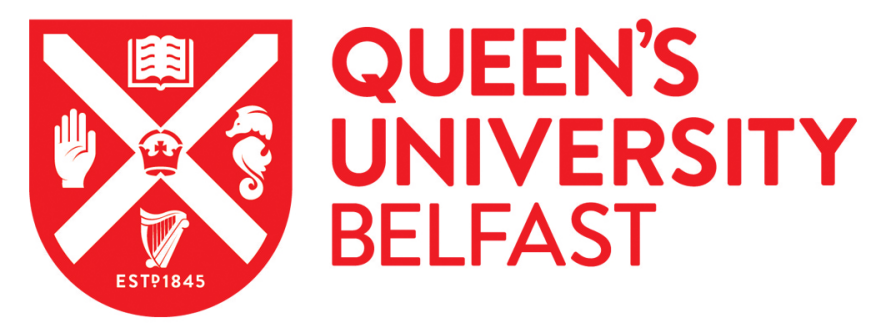

\title{
Infection with virulent strains of helicobacter pylori is not associated with ischaemic heart disease: evidence from a population-based case- control study of myocardial infarction
}

Murray, L., Bamford, K. B., Kee, F., McMaster, D., Cambien, F., Dallongeville, J., \& Evans, A. (2000). Infection with virulent strains of helicobacter pylori is not associated with ischaemic heart disease: evidence from a population-based case-control study of myocardial infarction. Atherosclerosis, 149(2), 379-385.

Published in:

Atherosclerosis

Queen's University Belfast - Research Portal:

Link to publication record in Queen's University Belfast Research Portal

\section{General rights}

Copyright for the publications made accessible via the Queen's University Belfast Research Portal is retained by the author(s) and / or other copyright owners and it is a condition of accessing these publications that users recognise and abide by the legal requirements associated with these rights.

Take down policy

The Research Portal is Queen's institutional repository that provides access to Queen's research output. Every effort has been made to ensure that content in the Research Portal does not infringe any person's rights, or applicable UK laws. If you discover content in the Research Portal that you believe breaches copyright or violates any law, please contact openaccess@qub.ac.uk. 


\title{
Infection with virulent strains of Helicobacter pylori is not associated with ischaemic heart disease: evidence from a population-based case-control study of myocardial infarction
}

\author{
Liam J. Murray ${ }^{\mathrm{a}, *}$, Kathy B. Bamford ${ }^{\mathrm{b}}$, Frank Kee ${ }^{\mathrm{a}}$, Dorothy McMaster ${ }^{\mathrm{c}}$, \\ Francois Cambien $^{\mathrm{d}}$, Jean Dallongeville ${ }^{\mathrm{e}}$, Alun Evans ${ }^{\mathrm{a}}$ \\ a Department of Epidemiology and Public Health, The Queen's University of Belfast, Mulhouse Building, Grosvenor Road, Belfast BT12 6BJ, UK \\ ${ }^{\mathrm{b}}$ Department of Infectious Diseases, Imperial College School of Medicine, London, UK \\ ${ }^{\mathrm{c}}$ Department of Medicine, The Queen's University of Belfast, Belfast, UK \\ d Inserm SC7, Paris, France \\ e Institut Pasteur, Lille, France
}

Received 14 December 1998; received in revised form 5 July 1999; accepted 30 July 1999

\begin{abstract}
Background: Although the majority of evidence does not support association between Helicobacter pylori infection and ischaemic heart disease, the nature of this relationship may differ when virulence of the infecting strains are examined. Methods and results: The prevalence of $\mathrm{IgG}$ antibody evidence of infection with CagA positive stains of $H$. pylori was investigated in stored plasma samples from 259 cases of myocardial infarction (aged 25-70 years, 74 males) and 259 population based controls from the same area in Northern Ireland. Two-hundred and seventy $(52.1 \%)$ subjects were seropositive for anti-CagA IgG. CagA seropositivity was more common in cases than in controls: 56.4 vs $47.9 \%$, odds ratio for seropositivity in cases $(95 \% \mathrm{CI}) 1.41$ (1.00, 1.99). Substantial attenuation of this relationship occurred on adjustment for age, sex, number of siblings, smoking and measures of socio-economic status: odds ratio $(95 \% \mathrm{CI}) 1.16(0.79,1.70)$. A similar pattern was seen for seropositivity for all $\mathrm{H}$. pylori strains. Conclusion: Infection with the more virulent strains of $H$. pylori, as with all strains, is not associated with myocardial infarction. (c) 2000 Elsevier Science Ireland Ltd. All rights reserved.
\end{abstract}

Keywords: Helicobacter pylori; Virulence; Myocardial infarction

\section{Introduction}

The relationship between Helicobacter pylori (H. pylori) infection and ischaemic heart disease (IHD) has been well investigated. Early reports of an association between infection and IHD [1,2] have not been substantiated in larger [3] and better designed studies [4,5] and current consensus opinion is that infection with $H$. pylori infection is not a risk factor for IHD. However, a recently published report [6] has shifted the focus

\footnotetext{
* Corresponding author. Tel.: + 44-1232-240503, extn 2620; fax: + 44-1232-231907.

E-mail address: 1.murray@qub.ac.uk (L.J. Murray)
}

onto infection with virulent forms of the organism i.e. those possessing the cytotoxin-associated gene-A (CagA). These strains induce a stronger inflammatory response [7], are more ulcerogenic [8], and are more strongly associated with gastric cancer than CagA negative strains [9]. A strong association with IHD has been observed [6] which appears to be free from the confounding effects of socio-economic status in childhood. It is possible that previous studies of $H$. pylori and IHD have failed to observe positive associations because virulence factors were not examined. We examine the relationship between infection with virulent strains of $H$. pylori and IHD in a population based case-control study of myocardial infarction. 


\section{Methods}

\subsection{The ECTIM Extension Study}

This study utilised stored plasma from Northern Irish subjects recruited into the ECTIM Extension Study, a case control study of IHD, with recruitment centres in Belfast and Glasgow. In Northern Ireland, myocardial infarction patients, aged $25-70$ at the time of infarct, and control subjects were recruited from Belfast and surrounding districts in the early 1990s. Both male and female cases were recruited (although the focus was on females) 3-9 months after an event which satisfied the WHO criteria for definite acute myocardial infarction [10]. Control subjects, resident in the same area, were randomly selected (with frequency matching for age and sex) from a centralised database of patients registered with general practitioners. Three hundred and one cases and 290 controls were recruited into the Belfast limb of the study. Cases and controls completed questionnaires and underwent a clinical examination according to a strict protocol. Data collected included age, sex, educational history, social class, sibship size, smoking status, alcohol intake, history of hypertension, hyperlipidaemia, diabetes, previous myocardial infarction or angina, other past medical history and the Rose angina and intermittent claudication questionnaires. The clinical examination included height, weight, blood pressure and waist and hip circumference. Fasting blood was taken for measurement of triglycerides, total-, HDL-, LDL- and VLDL-cholesterol, and apolipoproteins $\mathrm{A} 1$ and $\mathrm{B}$, as previously described [11]. Aliquots of plasma used in this study had been stored at $-70^{\circ} \mathrm{C}$ since collection.

\subsection{Laboratory methods}

Anti-CagA antibodies were measured using a commercial enzyme-linked immunosorbent assay (ELISA) (Invitech, UK). Optical densities were converted to semi-quantitative antibody levels using calibrator values according to the manufacturer's instructions. Specimens with an IgG level greater than $7.5 \mathrm{U}$ were classified as positive with further categorisation of seropositive status into moderately (7.5-24.9 U), strongly (25-49.9 $\mathrm{U})$ and very strongly positive (50 U or higher).

$H$. pylori specific IgG antibodies were measured by an in-house ELISA using an acid-glycine extract of $H$. pylori NCTC 11638. This assay and the derivation of the threshold for seropositivity has been described in detail elsewhere [12]. In addition to categorisation of subjects into $H$. pylori seronegative or seropositive, positive antibody responses were graded into weakly, moderately, strongly and very strongly positive.

\subsection{Statistical/analytical methods}

In all analyses, social class (coded according to the OPCS classification of occupations [13]) educational attainment, smoking status, alcohol intake and number of siblings were used as categorical variables (Table 1) while age, body mass index, systolic and diastolic blood pressure, triglycerides, apolipoproteins $\mathrm{A} 1$ and $\mathrm{B}$, total, HDL-, LDL- and VLDL-cholesterol were treated as continuous untransformed variables. The relationships between CagA and H. pylori seropositivity, socio-demographic and lifestyle variables and cardiovascular risk factors were examined in the controls using bi-variable analyses - the independent samples $t$-test and $\chi^{2}$ test. Observed associations between possession of anti-CagA or anti-H. pylori $\mathrm{IgG}$ and smoking status and number of siblings were adjusted, using multiple logistic regression, for age, sex and measures of socioeconomic status. Logistic regression models were manually constructed with case-control status as the dependent variable, CagA or H. pylori seropositivity as predictor variables and age, sex, socio-economic status, number of siblings and smoking status as potential confounders.

\section{Results}

This report is based on 259 cases ( $86 \%$ of cases in the Belfast ECTIM Extension Study) and 259 controls ( $89 \%$ of controls) for whom stored plasma was available. Seventy-four cases and controls $(28.6 \%)$ were male. Two hundred and seventy (52.1\%) and 341 $(65.8 \%)$ subjects were seropositive for anti-CagA and anti- $H$. pylori IgG respectively. Forty-six subjects $(8.8 \%)$ possessed anti-CagA antibodies but not anti- $H$. pylori IgG antibodies and 117 (22.5\%) were seropositive for anti- $H$. pylori but not anti-CagA IgG.

Table 1 shows the relationships, in the controls, between anti-CagA and anti-H. pylori antibody status and socio-demographic, lifestyle and cardiovascular risk factors. Seropositivity for anti-CagA IgG was not associated with age, sex, social class, or educational attainment but was associated with smoking status and number of siblings. Prevalence of anti-H. pylori IgG was associated with social class, smoking status and number of siblings and prevalence was higher in older age groups and in subjects with lower educational attainment but this relationship did not achieve statistical significance. CagA and H. pylori seropositivity were not associated with systolic or diastolic blood pressure, body mass index, or any of the lipid or lipoprotein variables.

Both CagA and $H$. pylori seropositivity remained associated with smoking status on adjustment for age, sex, social class and educational attainment; odds ratio 
Table 1

CagA and H. pylori seropositivity in controls: relationships with sociodemographic, lifestyle and cardiovascular risk factors

\begin{tabular}{|c|c|c|c|c|c|c|c|c|c|}
\hline & & \multirow{2}{*}{$\begin{array}{l}\text { CagA seronega- } \\
\text { tive } \\
\text { Number }\end{array}$} & \multicolumn{3}{|c|}{ CagA seropositive } & \multirow{2}{*}{$\begin{array}{l}\text { H. pylori seronega- } \\
\text { tive } \\
\text { Number }\end{array}$} & \multicolumn{3}{|c|}{ H. pylori seropositive } \\
\hline & & & Number $(\%)$ & $\begin{array}{l}\left.\chi^{2} \text { (for trend }\right) \\
\text { value }\end{array}$ & $P$-value & & Number $(\%)$ & $\begin{array}{l}\chi^{2} \text { for trend } \\
\text { value }\end{array}$ & $P$-value \\
\hline Age group & Less than 50 & 13 & $9(41.0)$ & & & 9 & $13(59.1)$ & & \\
\hline \multirow[t]{5}{*}{$N=259$} & $50-54$ & 16 & $14(46.7)$ & & & 16 & $14(46.7)$ & & \\
\hline & $55-59$ & 25 & $11(30.6)$ & & & 20 & $16(44.4)$ & & \\
\hline & $60-64$ & 29 & $41(58.6)$ & & & 19 & $51(72.8)$ & & \\
\hline & $65-69$ & 39 & $34(46.6)$ & & & 28 & $46(62.2)$ & & \\
\hline & 70 or more & 13 & $15(53.6)$ & 1.42 & 0.23 & 10 & $18(64.3)$ & 2.86 & 0.09 \\
\hline Sex & Male & 38 & $36(48.6)$ & & & 30 & $44(59.5)$ & & \\
\hline$N=259$ & Female & 97 & 88 (47.6) & 0.03 & 0.87 & 71 & 114 (61.6) & 0.1 & 0.75 \\
\hline Social class & Manual & 59 & $59(50.0)$ & & & 30 & $88(74.5)$ & & \\
\hline$N=255$ & Non-manual & 75 & $62(45.3)$ & 0.57 & 0.49 & 68 & $69(50.4)$ & 15.6 & $<0.001$ \\
\hline $\begin{array}{l}\text { Educational at- } \\
\text { tainment }\end{array}$ & University degree & 13 & $12(48.0)$ & & & 12 & $13(52.0)$ & & \\
\hline \multirow[t]{3}{*}{$N=259$} & $\begin{array}{l}\text { Other post school qual- } \\
\text { ification }\end{array}$ & 21 & $25(54.3)$ & & & 20 & $26(56.5)$ & & \\
\hline & Secondary school & 39 & $22(36.1)$ & & & 26 & $35(57.4)$ & & \\
\hline & Primary school & 62 & $65(51.2)$ & 0.02 & 0.88 & 43 & $84(66.1)$ & 2.66 & 0.1 \\
\hline Smoking status & Never smoked & 81 & $56(40.8)$ & & & 63 & $74(54.0)$ & & \\
\hline \multirow[t]{2}{*}{$N=259$} & Ex-smoker & 32 & $34(51.5)$ & & & 25 & $41(62.1)$ & & \\
\hline & Current smoker & 21 & $32(60.4)$ & 6.32 & 0.01 & 13 & $40(75.5)$ & 7.30 & 0.007 \\
\hline Alcohol intake & None & 60 & 43 (41.7) & & & 39 & $64(62.1)$ & & \\
\hline \multirow[t]{3}{*}{$N=259$} & Occasional & 30 & $22(42.3)$ & & & 21 & $31(59.6)$ & & \\
\hline & 1-3 days a week & 35 & $50(58.8)$ & & & 34 & $51(60.0)$ & & \\
\hline & 4-7 days a week & 10 & $9(47.3)$ & 3.6 & 0.06 & 7 & $12(63.2)$ & 0.023 & 0.88 \\
\hline \multicolumn{10}{|l|}{$\begin{array}{l}\text { Number of sib- } \\
\text { lings }\end{array}$} \\
\hline \multirow[t]{4}{*}{$N=259$} & 0,1 & 46 & $33(41.7)$ & & & 40 & $39(49.4)$ & & \\
\hline & 2,3 & 47 & 30 (38.9) & & & 31 & $46(59.7)$ & & \\
\hline & 4,5 & 22 & $33(60.0)$ & & & 16 & 39 (70.9) & & \\
\hline & 6 or more & 20 & $28(58.3)$ & 6.05 & 0.01 & 14 & $34(70.8)$ & 7.93 & 0.005 \\
\hline
\end{tabular}


Table 1 (Continued)

\begin{tabular}{|c|c|c|c|c|c|c|c|c|}
\hline & \multirow{2}{*}{$\begin{array}{l}\text { CagA seronega- } \\
\text { tive } \\
\text { Number }\end{array}$} & \multicolumn{3}{|c|}{ CagA seropositive } & \multirow{2}{*}{$\begin{array}{l}\text { H. pylori seronega- } \\
\text { tive } \\
\text { Number }\end{array}$} & \multicolumn{3}{|c|}{ H. pylori seropositive } \\
\hline & & Number $(\%)$ & $\begin{array}{l}\chi^{2} \text { (for trend) } \\
\text { value }\end{array}$ & $P$-value & & Number $(\%)$ & $\begin{array}{l}\chi^{2} \text { for trend } \\
\text { value }\end{array}$ & $P$-value \\
\hline $\begin{array}{l}\text { Body mass index }(\mathrm{kg} / \\
\left.\mathrm{m}^{2}\right)\end{array}$ & 25.9 & 26.2 & 0.45 & 0.65 & 26.1 & 26.1 & 0.11 & 0.91 \\
\hline $\begin{array}{l}\text { Systolic blood pressure } \\
(\mathrm{mmHg})\end{array}$ & 145.3 & 143.8 & 0.59 & 0.55 & 143.1 & 145.5 & 0.93 & 0.35 \\
\hline $\begin{array}{l}\text { Diastolic blood pressure } \\
(\mathrm{mmHg})\end{array}$ & 81.9 & 80.6 & 1.05 & 0.29 & 81.4 & 81.2 & 0.18 & 0.35 \\
\hline $\begin{array}{l}\text { Total cholesterol } \\
(\mathrm{mmol} / \mathrm{l})\end{array}$ & 2.28 & 2.29 & 0.28 & 0.78 & 2.27 & 2.30 & 0.61 & 0.54 \\
\hline $\mathrm{HDL}(\mathrm{mmol} / \mathrm{l})$ & 0.51 & 0.51 & 0.02 & 0.98 & 0.51 & 0.51 & 0.24 & 0.81 \\
\hline $\mathrm{LDL}(\mathrm{mmol} / \mathrm{l})$ & 1.48 & 1.50 & 0.46 & 0.65 & 1.47 & 1.50 & 0.74 & 0.46 \\
\hline VLDL $(\mathrm{mmol} / \mathrm{l})$ & 0.30 & 0.30 & 0.15 & 0.88 & 0.29 & 0.29 & 0.31 & 0.78 \\
\hline Triglycerides $(\mathrm{mmol} / \mathrm{l})$ & 1.52 & 1.50 & 0.19 & 0.85 & 1.51 & 1.51 & 0.01 & 0.99 \\
\hline Apolipoprotein A1 (g/l) & 1.57 & 1.53 & 0.9 & 0.36 & 1.57 & 1.54 & 0.87 & 0.38 \\
\hline Apolipoprotein B (g/1) & 1.32 & 1.32 & 0.08 & 0.94 & 1.31 & 1.32 & 0.36 & 0.72 \\
\hline
\end{tabular}


(95\% CI) for anti-CagA and anti-H. pylori IgG in current smokers compared to never smokers 2.05 (1.04, $4.01)$ and $2.34(1.09,5.01)$ respectively. When the relationship between $H$. pylori seropositivity and number of sibs was adjusted for age, sex, social class and educational attainment having more than one sibling was associated with seropositivity. There was a gradient in the odds ratio with increasing number of sibs: the odds (95\% CI) of having $2-3,4-5$ and 6 or more siblings in seropositives compared to seronegatives were 1.52 (0.77, 3.00), $2.32(1.07,5.05)$ and $2.66(1.22,5.78)$. A similar gradient was observed for CagA seropositivity but this did not achieve statistical significance: odds (95\% CI) of having $2-3,4-5$ and 6 or more siblings in seropositives compared to seronegatives were 0.86 (0.44, 1.68), 2.01 (0.97, 4.16), and $2.06(0.96,4.44)$ respectively.

On bi-variable analysis, CagA seropositivity was more common in cases than in controls (56.4 vs $47.9 \%$, $\left.\chi^{2} 3.74, P=0.05\right)$ as was anti- $H$. pylori seropositivity (70.7 vs $61 \%, \chi^{2} 5.36, P=0.02$ ). This was reflected in the modestly elevated unadjusted odds ratio $(95 \% \mathrm{CI})$ for $\mathrm{CagA}$ and $H$. pylori seropositivity in cases compared to controls: $1.41(1.00,1.99)$ and $1.54(1.07,2.22)$ respectively (Table 2). However, the ratios were decreased in magnitude and became statistically insignificant with adjustment for age, sex and measures of socio-economic status; odds ratios $(95 \% \mathrm{CI}), 1.27$ ( 0.88 , $1.83)$ and $1.23(0.83,1.81)$ respectively. These relationships were further attenuated after adjustment for number of siblings and smoking status; odds ratios $(95 \%$ CI), $1.16(0.79,1.70)$ and $1.08(0.72,1.62)$ respectively. No relationship was seen between strength of CagA and $H$. pylori antibody responses and case-control status when included in the models.

In both final logistic regression models, number of siblings remained associated with case-control status despite inclusion of measures of socio-economic and smoking status. For example, in the CagA model (i.e. case control status as the dependent variable and CagA

Table 2

Unadjusted and adjusted odds ratios of the relationship between CagA and H. pylori seropositivity and IHD

\begin{tabular}{lll}
\hline Adjusted for & $\begin{array}{c}\text { CagA seroposi- } \\
\text { tivity }(95 \% \mathrm{CI})\end{array}$ & $\begin{array}{l}\text { H. pylori seroposi- } \\
\text { tivity }(95 \% \mathrm{CI})\end{array}$ \\
\hline $\begin{array}{l}\text { Unadjusted } \\
\text { Age }\end{array}$ & $1.41(1.00,1.99)$ & $1.54(1.07,2.22)$ \\
$\begin{array}{c}\text { Age, sex, social class, ed- } \\
\text { ucational attainment }\end{array}$ & $1.27(0.88,1.83)$ & $1.23(0.83,1.81)$ \\
$\begin{array}{c}\text { Age, sex, social class, ed- } \\
\text { ucation level, number } \\
\text { of sibs }\end{array}$ & $1.22(0.84,1.77)$ & $1.13(0.76,1.68)$ \\
$\begin{array}{c}\text { Age, sex, social class, ed- } \\
\text { ucation level, number } \\
\text { of sibs, smoking status }\end{array}$ & $1.16(0.79,1.7)$ & $1.08(0.72,1.62)$ \\
\hline
\end{tabular}

seropositivity as the predictor variable) the odds (95\% CI) of cases having more than one sibling when compared to controls were $2.10(1.32,3.35)$. This association held with further adjustment for body mass index, blood pressure, and lipid and lipoprotein levels.

\section{Discussion}

The high prevalence of IgG antibodies to $H$. pylori observed in the controls in this study is in keeping with previous observations in middle-aged adults from the same area [12] and is most likely the product of relatively high levels of deprivation prevailing in Northern Ireland when the subjects were children. Antibodies to CagA positive strains of the organism were not as prevalent as anti- $H$. pylori antibodies but in most respects the epidemiology of CagA positive strains mirrored that of all strains e.g. both CagA seropositivity and $H$. pylori seropositivity were strongly associated with smoking status and with having more than one sibling. Smoking has previously been shown to be a risk factor for $H$. pylori infection [12,14,15], although there have been discrepant findings [16-18]. The fact that the relationship between CagA seropositivity and smoking is no stronger than for $H$. pylori seropositivity suggests that smoking is not a particular risk factor for infection with the more virulent strains of $H$. pylori. Number of siblings may reflect poor living conditions during childhood which are known to be risk factors for $H$. pylori infection [19-21] possibly through providing the environment in which the spread of infection within the household is facilitated. The association between $H$. pylori infection and smoking may also reflect poor living conditions during childhood rather than direct effects of smoking on susceptibility to the infection.

Almost 9\% of subjects were seropositive for CagA $\mathrm{IgG}$ but not for anti-H. pylori IgG. This indicates either a lack of sensitivity of the $H$. pylori ELISA or a lack of specificity of the CagA test. The former explanation may be more likely as the antigen utilised was prepared from only one strain of the organism although the test has been previously shown to have a sensitivity of $95 \%$ [12]. Whichever is the correct explanation, any misclassification of CagA or $\mathrm{H}$. pylori antibody status will act to reduce, to some extent, the ability of the study to observe an association between infection and IHD, should it exist.

In this study the unadjusted odds ratio for CagA seropositivity in cases compared to controls was only modestly elevated and was attenuated on adjustment for age, sex and measures of socio-economic status. Further adjustment for smoking status, number of siblings and cardiovascular risk factors reduced the magnitude of the odds ratio almost to unity. This finding conflicts with that of Pasceri et al. [6] who observed a 
substantially elevated odds ratio of CagA seropositivity, 3.8 (95\% CI 1.6-9.1), in a small study comparing subjects with angiographically demonstrated IHD to blood donor controls. These obviously discordant results, which may have their origin in differences in study size or design, impart a sense of deja vu in that the initial positive findings of association between $H$. pylori and IHD were not replicated in subsequent studies.

It is interesting that in the final regression models, number of siblings was strongly associated with casecontrol status, a finding which has been previously observed [22]. Larger families are likely to result in more frequent transmission of infections between siblings. Should one or more of these infections impart an increased risk of IHD in later life, association between number of siblings and IHD would be expected. This finding may therefore support an infective origin for cardiovascular disease but the infection conferring the risk is unlikely to be $H$. pylori or its virulent strains. Alternatively, number of siblings may be a proxy for poor socio-economic circumstances during childhood which influence adult cardiovascular disease risk via mechanisms unrelated to infection.

In conclusion, the principal finding of this study is that infection with the more virulent strains of $H$. pylori, as with all strains, is not a risk factor for IHD. This conflicts with recently published findings and further study of the relationship between infection with virulent $H$. pylori strains and IHD is indicated.

\section{Acknowledgements}

The ECTIM Extension Study was funded by the British Heart Foundation and Dr Murray was supported by the Eastern Health and Social Services Board (Northern Ireland) during this work. The authors wish to thank the research nurses to Belfast ECTIM Extension Study, Mary McConville and Ruth Leatham, and Barney O'Loughlin, Department of Microbiology and Immunology, the Queen's University of Belfast, who performed the CagA and $H$. pylori tests. Thanks are also due to Invitech (UK) Ltd who provided the CagA tests at lower than commercial rates.

\section{References}

[1] Mendall MA, Goggin PM, Molineaux N, Levy J, Toosy T, Strachan D, Camm AJ, Northfield TC. Relation of Helicobacter pylori and coronary heart disease. Br Heart J 1994;71:4379.
[2] Patel P, Mendall MA, Carrington D, Strachan DP, Leatham E, Molineaux N, Levy J, Blakeston C, Seymour CA, Camm AJ, Northfield TC. Association of Helicobacter pylori and Chlamydia pneumoniae infections with coronary heart disease and cardiovascular risk factors. Br Med J 1995;311:711-4.

[3] Murray LJ, Bamford KB, O'Reilly DPJ, McCrum EE, Evans AE. Helicobacter pylori infection: relation with cardiovascular risk factors, ischaemic heart disease, and social class. Br Heart J 1995;74:497-501.

[4] Whincup PH, Mendall MA, Perry IJ, Strachan DP, Walker M. Helicobacter pylori infection, coronary heart disease and stroke in middle-aged men; prospective relations in a nested case-control study. Heart 1996;75:568-72.

[5] Wald NJ, Law MR, Morris JK, Bagnall AM. Helicobacter pylori infection and mortality from ischaemic heart disease: negative result from a large, prospective study. $\mathrm{Br}$ Med J 1997;315:1199-201.

[6] Pasceri V, Cammarota G, Patti G, Cuoco L, Gasbarini A, Grillo RL, Fedeli G, Gasbarrini G, Maseri A. Association of virulent Helicobacter strains with ischemic heart disease. Circulation 1998;97:1675-9.

[7] Peek RM, Miller GG, Tham KT, Perez-Perez GI, Zhao X, Atherton JC, Blaser MJ. Heightened inflammatory response and cytokine expression in vivo to CagA + Helicobacter pylori strains. Lab Invest 1995;73:760-70.

[8] Figura N. Identifiable Helicobacter strains or factors important in the development of duodenal ulcer disease. Helicobacter 1997;2(Suppl. 1):S3-S12.

[9] Shimoyama T, Fukuda S, Tanaka M, Mikami T, Munakata A, Crabtree JE. CagA seropositivity associated with development of gastric cancer in a Japanese population. J Clin Pathol 1998;51:225-8.

[10] Tunstall Pedoe H, Kuulasmaa K, Amouyel P, Arveiler D, Rajakangas AM, Pajak A. Myocardial infarction and coronary deaths in the World Health Organisation MONICA Project. Registration procedures, event rates and case-fatality rates in 38 populations from 21 countries in four continents. Circulation 1994;90:583-612.

[11] Parra HJ, Arveiler D, Evans AE, Cambou JP, Amouyel P, Bingham A, McMaster D, Schaffer P, Douste-Blazy P, Luc G, Richard J, Ducimetiere P, Fruchart JC, Cambien F. A casecontrol study of lipoprotein particles in two populations at contrasting risk for coronary heart disease: the ECTIM Study. Arterioscler Thromb 1992;12:701-7.

[12] Murray LJ, Evans AE, McCrum EE, Bamford KB. Epidemiology of $H$. pylori infection among 4,742 randomly selected subjects from Northern Ireland. Int J Epidemiol 1997;26:880-7.

[13] Office of Population Censuses and Surveys GSS. Standard Occupational Classification. London: HMSO.

[14] Bateson MC. Cigarette smoking and Helicobacter pylori infection. Postgrad Med J 1993;69:41-4.

[15] Fontham ET, Ruiz B, Perez A, Hunter F, Correa P. Determinants of Helicobacter pylori infection and chronic gastritis. Am J Gastroenterol 1995;90(7):1094-101.

[16] The Eurogast Study Group. Epidemiology of, and risk factors for, Helicobacter pylori infection among 3194 asymptomatic subjects in 17 populations, Gut 1993;34:1672-1676.

[17] Sitas F, Forman D, Yarnell JWG, Burr ML, Elwood PC, Pedley S, Marks KJ. Helicobacter pylori infection rates in relation to age and social class in a population of Welsh men. Gut 1991;32:25-8.

[18] Graham DY, Malaty HM, Evans DG, Evans DJJ, Klein PD, Adam E. Epidemiology of Helicobacter pylori infection in an asymptomatic population in the United States: effect of age, 
race and socio-economic status. Gastroenterology 1991;100:1495-501.

[19] Mendall MA, Goggin PM, Molineaux N, Levy J, Toosy T, Strachan D, Northfield TC. Childhood living conditions and Helicobacter pylori seropositivity in adult life. Lancet 1992;339:896-7.

[20] Webb PM, Knight T, Greaves S, Wilson A, Newell DG. Relation between infection with Helicobacter pylori and living condi-tions in childhood: evidence for person to person transmission in early life. Br Med J 1994;308:750-3.

[21] Whitaker CJ, Dubiel AJ, Galpin OP. Social and geographical risk factors for Helicobacter pylori infection. Epidemiol Infect 1993;111:63-70.

[22] Burr ML, Sweetnam P. Family size and paternal unemployment in relation to myocardial infarction. J Epidemiol Community Health 1980;34:93-5. 